\title{
A Study on the High Load Operation of a Natural Gas-Diesel Dual-Fuel Engine
}

\author{
Shouvik Dev*, Hongsheng Guo and Brian Liko \\ Energy, Mining and Environment Research Center, National Research Council Canada, Ottawa, ON, Canada
}

Diesel fueled compression ignition engines are widely used in power generation and freight transport owing to their high fuel conversion efficiency and ability to operate reliably for long periods of time at high loads. However, such engines generate significant amounts of carbon dioxide $\left(\mathrm{CO}_{2}\right)$, nitrogen oxides ( $\mathrm{NOx}$ ), and particulate matter (PM) emissions. One solution to reduce the $\mathrm{CO}_{2}$ and particulate matter emissions of diesel engines while maintaining their efficiency and reliability is natural gas (NG)-diesel dual-fuel combustion. In addition to methane emissions, the temperatures of the diesel injector tip and exhaust gas can also be concerns for dual-fuel engines at medium and high load operating conditions. In this study, a single cylinder NG-diesel dual-fuel research engine is operated at two high load conditions (75\% and 100\% load). NG fraction and diesel direct injection (DI) timing are

OPEN ACCESS

Edited by:

Xiaosong $\mathrm{Hu}$,

Chongqing University, China

Reviewed by:

Alpaslan Atmanli,

National Defense University, Turkey

Md Nurun Nabi,

Central Queensland University,

Australia

Amin Paykani,

University of Hertfordshire,

United Kingdom

${ }^{*}$ Correspondence:

Shouvik Dev

shouvik.dev@nrc-cnrc.gc.ca

Specialty section:

This article was submitted to

Engine and Automotive Engineering,

a section of the journal

Frontiers in Mechanical Engineering

Received: 24 March 2020 Accepted: 17 November 2020

Published: 10 December 2020

Citation:

Dev S, Guo H and Liko B (2020) A Study on the High Load Operation of a Natural Gas-Diesel Dual-Fuel Engine.

Front. Mech. Eng. 6:545416.

doi: 10.3389/fmech.2020.545416 two of the simplest control parameters for optimization of diesel engines converted to dualfuel engines. In addition to studying the combined impact of these parameters on combustion and emissions performance, another unique aspect of this research is the measurement of the diesel injector tip temperature which can predict potential coking issues in dual-fuel engines. Results show that increasing NG fraction and advancing diesel direct injection timing can increase the injector tip temperature. With increasing NG fraction, while the methane emissions increase, the equivalent $\mathrm{CO}_{2}$ emissions (cumulative greenhouse gas effect of $\mathrm{CO}_{2}$ and $\mathrm{CH}_{4}$ ) of the engine decrease. Increasing NG fraction also improves the brake thermal efficiency of the engine though NOx emissions increase. By optimizing the combustion phasing through control of the DI timing, brake thermal efficiencies of the order of $\sim 42 \%$ can be achieved. At high loads, advanced diesel DI timings typically correspond to the higher maximum cylinder pressure, maximum pressure rise rate, brake thermal efficiency and NOx emissions, and lower soot, CO, and $\mathrm{CO}_{2}$-equivalent emissions.

Keywords: natural gas, dual-fuel, compression ignition, high load, greenhouse gas reduction

\section{INTRODUCTION}

As part of the Paris Agreement on climate change, Canada has committed to 30\% abatement of its greenhouse gas (GHG) emissions from the 2005 levels by the year 2030 (Government of Canada, 2016). As means of achieving this target, Canada has also been developing the Clean Fuel Standard since 2016 with the aim to reduce GHG emissions through use of "lower carbon fuels, energy sources and technologies" (Government of Canada, 2019).

Diesel fueled compression ignition (CI) engines are widely used in power generation and freight transport owing to their high fuel conversion efficiency and ability to operate reliably for long periods of time at high loads. Owing to their ubiquity and extent of use, the carbon dioxide $\left(\mathrm{CO}_{2}\right)$, nitrogen 
oxides (NOx) and particulate matter (PM) emissions from these engines can cause a significant adverse impact on the environment. Natural gas (NG) and renewable natural gas (RNG) are lower carbon and renewable fuels which generate about $20-30 \%$ and $80-90 \%$, respectively, lower life-cycle $\mathrm{CO}_{2}$ emissions per unit of energy compared to diesel (Sharpe, 2019). One solution to reduce the $\mathrm{CO}_{2}$ and $\mathrm{PM}$ emissions of diesel engines while maintaining their efficiency and reliability is to replace diesel by NG using diesel-NG dual-fuel combustion technology. A possible configuration of an NG-diesel dual-fuel engine is intake port injection of compressed NG to form a homogenous air/NG mixture in the cylinder, and ignition of this mixture using a direct injection (DI) of diesel. In addition to offsetting diesel consumption, the potential advantages of such a configuration are lower PM emissions and limited engine modifications (Sahoo et al., 2009). Besides, such dual-fuel engines can operate as conventional diesel engines when NG is not available. One of the main disadvantages of NG-diesel dualfuel engines is the higher methane emissions in comparison to conventional diesel engines (Liu et al., 2013; Guo et al., 2015). The global warming potential of methane over 100 years is 25 times that of $\mathrm{CO}_{2}$ (United States Environmental Protection Agency, 2020). Moreover, methane is difficult to oxidize effectively in the exhaust after-treatment (EAT) system (Osman, 2016; Gärtner et al., 2018). Methane emissions can therefore offset the advantage of lower $\mathrm{CO}_{2}$ emissions of the dual-fuel engines, especially at low load conditions. Advanced combustion strategies have been proposed that can minimize the methane emissions at low loads (Srinivasan et al., 2006; Guo et al., 2017; Yousefi et al., 2018). At medium to high load conditions, owing to the high fueling rate and higher temperatures which result in higher flame propagation speed, methane emissions are much lower than that at low load conditions, but they may still be greater than those of diesel engines (Papagiannakis and Hountalas, 2003). The main sources of these methane emissions at medium to high load conditions are crevice regions (Yousefi et al., 2019).

NG-diesel dual-fuel engines have been studied extensively over the years. There are many examples in literature that have summarized the fundamental performance of such dualfuel engines (Karim, 1980; Wagemakers and Leermakers, 2012; Wei and Geng, 2016). There have also been researches on the effect of the injection parameters of NG and diesel of dual-fuel engines with the aim to improve engine efficiency and reduce methane emissions (Figer et al., 2014; Yang et al., 2015; Guo et al., 2017). Increasing the NG fraction in the total fuel energy input, especially at low and intermediate loads, can cause the brake thermal efficiency (BTE) to decrease and the carbon monoxide and methane emissions to increase (Papagiannakis et al., 2010; Imran et al., 2014). Increasing the NG fraction also tends to cause higher maximum pressure rise rate and lower maximum combustion pressure (Sahoo et al., 2009). However, at all engine loads and speeds, increasing the NG fraction tends to decrease NOx and soot emissions (Papagiannakis et al., 2010). The reduced NOx emissions with increased NG fraction can be caused by the increase in the higher specific heat capacity of the NG-air gas mixture and the lower maximum combustion pressure (Imran et al., 2014). One way to counter the reduced efficiency associated with higher NG fraction is to advance the timing of the diesel injection and increase the diesel injection pressure (Sahoo et al., 2009; Yang et al., 2015). However, this is accompanied by an increase in the NOx emissions and maximum combustion pressure and pressure rise rate (Sahoo et al., 2009). Therefore, there exists a trade-off between NOx-methane emissions for dual-fuel combustion (Wei and Geng, 2016). Additionally, there is an insignificant effect of NG injection timing on combustion performance and emissions at the advanced diesel injection timings (Yang et al., 2015).

The authors' laboratory has previously studied pollutant emissions from dual-fuel engines including the pollutant formation mechanisms (Guo et al., 2017; Li et al., 2018). The present work builds on the previous research by studying the effect of increasing NG fraction and DI timing (of diesel) on engine performance and exhaust emissions at high load-low speed operating conditions. Potential application of such research is the conversion of existing diesel engines to dualfuel engines in which the diesel DI timing and NG fraction can be the simplest control parameters for optimization without extensive engine hardware modification. An additional and unique metric deployed in this research is the injector tip temperature. Dual-fuel engines with the capability to operate in diesel-only mode tend to use the stock diesel injectors. When operating in dual-fuel mode, the diesel flow rate through the injector may be significantly reduced. Since the diesel also functions as a coolant to reduce the injector tip temperature, the reduced diesel flow rate may cause over-heating and potential coking inside the injector nozzles. This can disrupt the diesel injection and adversely affect the performance of the engine. Past investigations have found that injector coking problems increased when the injector tip temperature exceeded $300^{\circ} \mathrm{C}$ (Argueyrolles et al., 2007). Research on injector tip temperature for NG-diesel dual-fuel engines is limited. Königsson et al. found that increasing NG fraction caused the injector tip temperature to increase (Königsson et al., 2012). The authors' laboratory conducted research on injector tip temperature at a constant NG fraction of 75\% (Guo and Liko, 2018). This study furthers the analysis of injector tip temperature at different $\mathrm{NG}$ fractions with the goal to determine if the $300^{\circ} \mathrm{C}$ threshold can be reached in high load dual-fuel operation. Based on the authors' search, this reported work is unique in its representation of the correlations between NG fraction, diesel DI timing, and injector tip temperature.

In this paper, two high load conditions $-75 \%$ and $100 \%$ load are investigated. The two main variables are the NG fraction and the diesel DI timing of the diesel injection. Combustion performance, injector tip temperature and exhaust emissions are evaluated. The paper is organized as follows. Experimental setup and procedure as well as test conditions are described in Experimental Setup and Methods, followed by the discussion of results in Results and Discussion which consists of three sub-sections describing the combustion performance, injector tip temperature and exhaust emissions. The main conclusions of this research are presented in Conclusions. 
TABLE 1 | Test engine specifications and fuel properties.

Base engine model

Number of cylinders

Bore X stroke

Displacement

Compression ratio

Number of valves

Maximum power output (stock)

Fuel delivery-diesel

Diesel density

Diesel cetane number

Diesel lower heating value

Diesel hydrogen/Carbon ratio

Fuel delivery-natural gas

Natural gas composition (by volume)

Natural gas lower heating value
Caterpillar 3401 (3400 series)

$137.2 \times 165.1 \mathrm{~mm}$

$2.44 \mathrm{~L}$

16.25:1

4 (2-intake, 2-exhaust)

$74.6 \mathrm{~kW}$ (at 2,100 rpm)

Common rail direct injection

$814.8 \mathrm{~kg} / \mathrm{m}^{3}$

44

44.64 $\mathrm{MJ} / \mathrm{kg}$ at $15^{\circ} \mathrm{C}$ and $1 \mathrm{~atm}$

1.90

Port fuel injection

Methane (94.951\%); ethane (3.318\%); propane (0.087\%); butane $(0.003 \%)$; nitrogen $(0.929 \%)$; carbon dioxide $(0.712 \%)$ $33.77 \mathrm{MJ} / \mathrm{m}^{3}$ at $15^{\circ} \mathrm{C}$ and $1 \mathrm{~atm}$

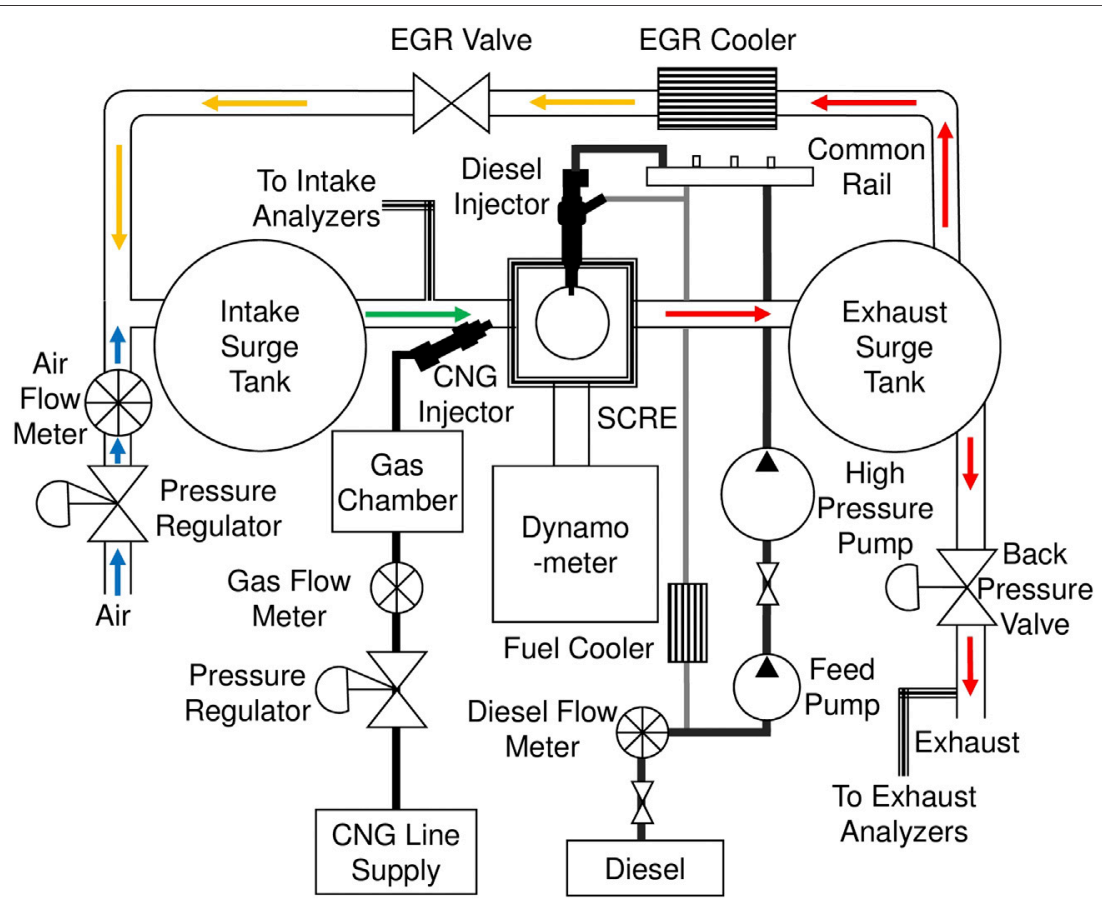

FIGURE 1 | Schematic of experimental setup.

\section{EXPERIMENTAL SETUP AND METHODS}

This section is organized into two sub-sections. The first subsection on experimental setup describes the testing system in detail. The second sub-section describes the experimental procedure and conditions, including calculation methods, test parameters and hardware constraints.

\section{Experimental Setup}

The research was performed on a single cylinder research engine. The setup consisted of a Caterpillar 3401 heavy-duty, four-stroke diesel engine coupled with a $131 \mathrm{~kW}$ eddy current dynamometer.
The specifications of the engine are given in Table 1 and the schematic of the experimental setup is shown in Figure 1. A DC electric motor was used for starting and motoring of the engine.

The test setup also included a gas injection manifold in-line and immediately upstream of the intake port of the engine. Compressed NG was supplied by the local utility provider (Enbridge, Inc.) through their pipeline infrastructure into the test cell directly and a pressure regulator was used to maintain the injection pressure. A Bronkhorst mass flow meter was used to measure the flow rate of NG into the engine. Downstream of the flow meter and upstream of the gas injection manifold, a gas chamber was used to dampen any pressure pulses in the flow. The 


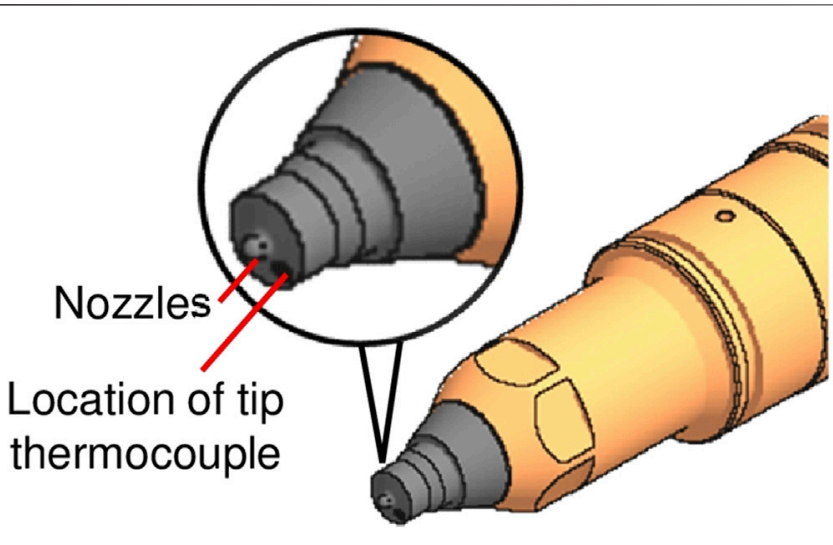

FIGURE 2 | Injector tip temperature measurement.

gas injection manifold consisted of eight gas fuel solenoid injectors (model Gs60 manufactured by Alternative Fuel Systems (AFS) Incorporated) which were individually controlled to inject precise quantities of NG into the intake charge of the engine. Since the composition of NG in the supply line may vary, the NG composition was determined before the tests using an Ametek Model 292B BTU Analyzer. The result is shown in Table 1. A custom diesel common rail DI system consisting of a Ganser six-hole solenoid injector and a high pressure fuel pump operated independent of the engine was used to deliver diesel to the engine. The diesel injector had a K-type thermocouple mounted into the sidewall to measure the injector tip temperature. The location of this thermocouple with respect to the nozzle is shown in Figure 2. The properties of the Canadian ultra-low-sulphur diesel (ULSD) used in this study are listed in Table 1. The diesel flow rate was measured with a Bronkhorst flow meter. The diesel and NG fueling were controlled by National Instruments (NI) hardware and LabVIEW based software (Stand-alone Direct Injector Drive System, Drivven Inc.). The hardware consisted of NI PXI-1031 chassis with NI PXI-8184 embedded controller, NI cRIO-9151 expansion chassis, and NI 7813R RIO injector driver card (for the diesel injector). The PXI-8184 controlled two four-channel AFS Injector Driver modules to drive the eight gas injectors.

The engine was aspirated with a conditioned air supply system with independent control of air pressure (oil-free air compressor and pressure regulators) and in-line intake heating. The air flow rate was measured with a thermal wire-type mass flowmeter manufactured by Sierra Instruments Inc. Intake and exhaust surge tanks were installed in the intake loop and the exhaust loop to dampen pressure waves in the system. An electropneumatic back pressure valve was used to simulate back pressure from the turbocharger. The lubricating oil and engine coolant conditioning systems were also operated independent of the engine with both oil and coolant temperatures maintained at $85^{\circ} \mathrm{C}$.

CAI 600 series gas analyzers were used to determine the concentrations of $\mathrm{CO}, \mathrm{CO}_{2}, \mathrm{CH}_{4}$, total $\mathrm{HC}, \mathrm{O}_{2}$, and $\mathrm{NOx}$ in the engine exhaust. An AVL $415 \mathrm{~S}$ smoke meter was used to
TABLE 2 | Experimental conditions.

\begin{tabular}{|c|c|c|}
\hline Parameter & $75 \%$ full load & $100 \%$ full load \\
\hline BMEP (bar) & 12.86 & 17.65 \\
\hline $\mathrm{T}_{\text {in }}\left({ }^{\circ} \mathrm{C}\right)$ & \multicolumn{2}{|c|}{40} \\
\hline Diesel $p_{\text {injection }}(\mathrm{bar})$ & \multicolumn{2}{|c|}{525} \\
\hline$N G$ pinjection (bar) & \multicolumn{2}{|c|}{4.83} \\
\hline Engine speed (N) (rpm) & 1,010 & 1,120 \\
\hline Intake pressure $\left(\mathrm{p}_{\mathrm{in}}\right)$ (bar absolute) & 1.6 & 2.2 \\
\hline Exhaust pressure $\left(\mathrm{p}_{\mathrm{ex}}\right)$ (bar absolute) & 1.3 & 1.6 \\
\hline$\alpha_{N G}(\%)$ & 0-90 & $0-65$ \\
\hline
\end{tabular}

determine the soot emissions. The filter smoke number (FSN) output of the smoke meter was converted to mass concentration $\left(m_{\text {soot }}\right.$ in $\left.\mathrm{mg} / \mathrm{m}^{3}\right)$ using Eq. 1 (Christian et al., 1993).

$$
m_{\text {soot }}=\frac{1}{0.405} \times 4.95 \times \mathrm{FSN} \times e^{0.38 \times \mathrm{FSN}} .
$$

Additional instrumentation of the engine included the watercooled, flush-mounted Kistler 6041A pressure transducer for measuring cylinder pressure and an AVL 365 series crank angle encoder. The outputs of the pressure transducer and the encoder were processed using AVL IndiModule combustion analysis system. Engine load and speed were controlled through the AVL Digalog Testmate system. Thermocouples were mounted at multiple locations in the test cell to monitor temperature. The test cell was also equipped with an exhaust gas recirculation (EGR) loop though it was not used in this research. Further details of the test setup are described in Guo and Liko (2018).

\section{Experimental Procedure and Conditions}

In NG-diesel dual-fuel engines, a primary parameter is the NG fraction (denoted by " $\alpha_{\mathrm{NG}}$ "). This was calculated using Eq. 2. $\alpha_{\mathrm{NG}}=0 \%$ indicated that all input fuel energy came from diesel.

$$
\alpha_{\mathrm{NG}}=100 \times \frac{m_{\mathrm{NG}} \mathrm{LHV}_{\mathrm{NG}}}{m_{\mathrm{NG}} \mathrm{LHV}_{\mathrm{NG}}+m_{\mathrm{D}} \mathrm{LHV}_{\mathrm{D}}} .
$$

where, " $m$ " and "LHV" were the mass flow rate $(\mathrm{kg} / \mathrm{s})$ and lower heating value $(\mathrm{MJ} / \mathrm{kg})$, respectively, and the subscripts "NG" and " $\mathrm{D}$ " represented natural gas and diesel, respectively.

The cylinder pressure data was stored for 100 consecutive engine cycles at a resolution of 0.2 crank angle degree (CAD). This data was used to calculate the net heat release rate (" $H R R_{\text {net }}$ " in J/CAD) using Eq. 3.

$$
\mathrm{HRR}_{\text {net }}=\frac{1}{\gamma-1}\left[\gamma p \frac{\mathrm{d} V}{\mathrm{~d} \theta}+V \frac{\mathrm{d} p}{\mathrm{~d} \theta}\right] .
$$

In Eq. 3, " $\gamma$ " was the ratio of the specific heat at constant pressure to the specific heat at constant volume and was calculated as a function of the in-cylinder gas temperature and composition, " $p$ " was the in-cylinder pressure $(\mathrm{Pa})$, " $V$ " was the cylinder volume $\left(\mathrm{m}^{3}\right)$ and " $\theta$ " was the crank angle (CAD). The heat release analysis was used to calculate the combustion timing values such as start of combustion (denoted by "CA10"), 

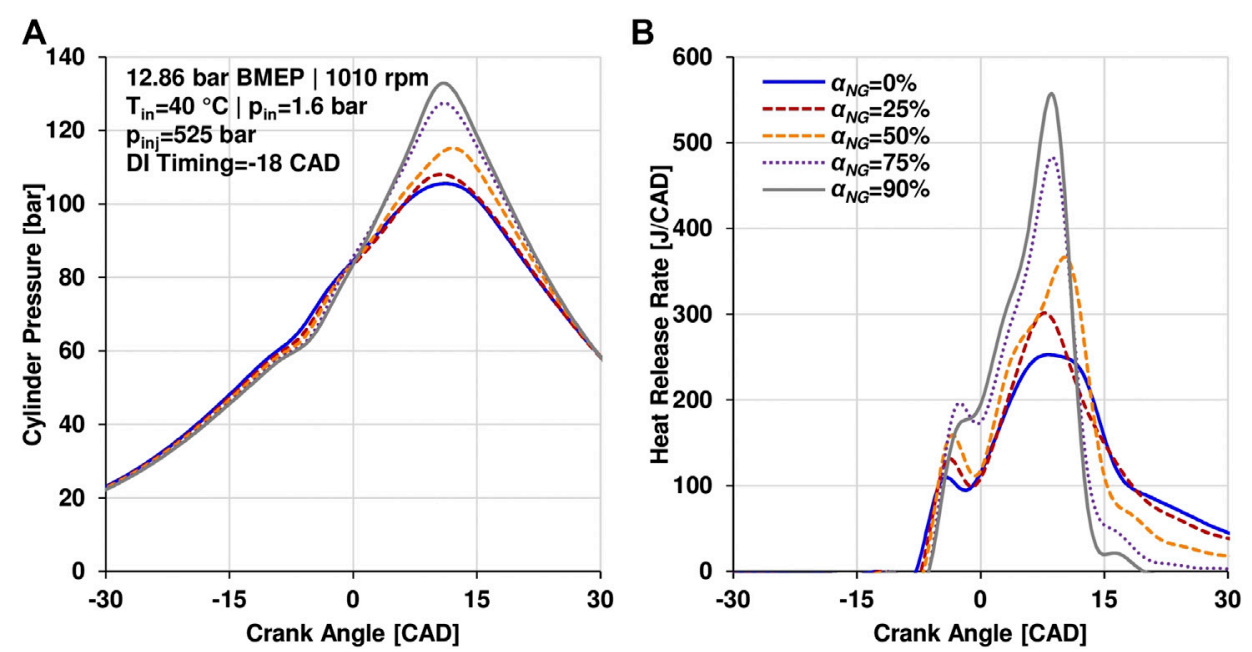

FIGURE 3 | 75\% load-(A). Cylinder pressure; (B). Heat release rate.
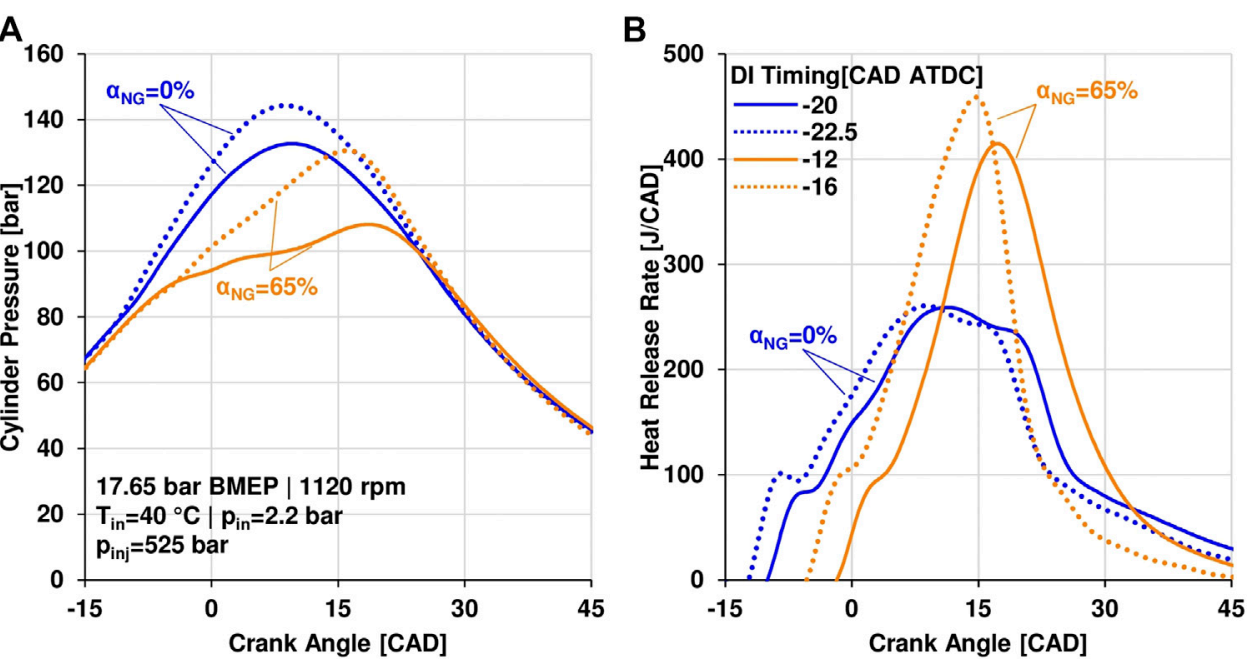

FIGURE 4 | 100\% load-(A). Cylinder pressure; (B). Heat release rate.

combustion phasing (denoted by "CA50") and end of combustion (denoted by "CA90"). CA10, CA50, and CA90 corresponded to the specific crank angles at which $10 \%, 50 \%$ and $90 \%$, respectively, of the total heat release occurred. Combustion duration was denoted by CA10-90.

The brake thermal efficiency (BTE) was used as a measure of the engine efficiency. It was expressed as a percentage and

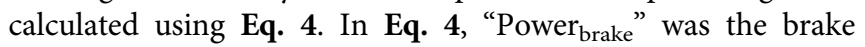
power of the engine measured by the dynamometer $(\mathrm{kW})$, "LHV" was the lower heating value of the NG-diesel fuel combination $(\mathrm{kJ} / \mathrm{kg})$, and " $m_{f}$ " was the mass flow rate of the NG-diesel fuel combination (kg/hour).

$$
\mathrm{BTE}=100 \times \frac{3600 \times \text { Power }_{\text {brake }}}{\mathrm{LHV}_{f} \times m_{f}} .
$$

The experiments consisted of detailed investigation of combustion performance at two typical high load conditions-12.86 and 17.65 bar brake mean effective pressure (BMEP) at engine speeds of 1,010 and $1,120 \mathrm{rpm}$ respectively corresponding to $75 \%$ and $100 \%$ load respectively. These choices were based on a previous study in which the highest injector tip temperatures had been observed between $75 \%$ and $100 \%$ load especially at low engine speeds of $\sim 1,000 \mathrm{rpm}$ albeit at a fixed NG fraction of 75\% (Guo and Liko, 2018). The lower engine speeds were consistent with the trend of downspeeding of heavy-duty engines especially in transportation applications in the interest of increasing fuel efficiency. While the original intention was to operate the engine at $\sim 1,000 \mathrm{rpm}$ for the $100 \%$ load condition as well, in the interest of maintaining the load and stability over varying NG fractions 

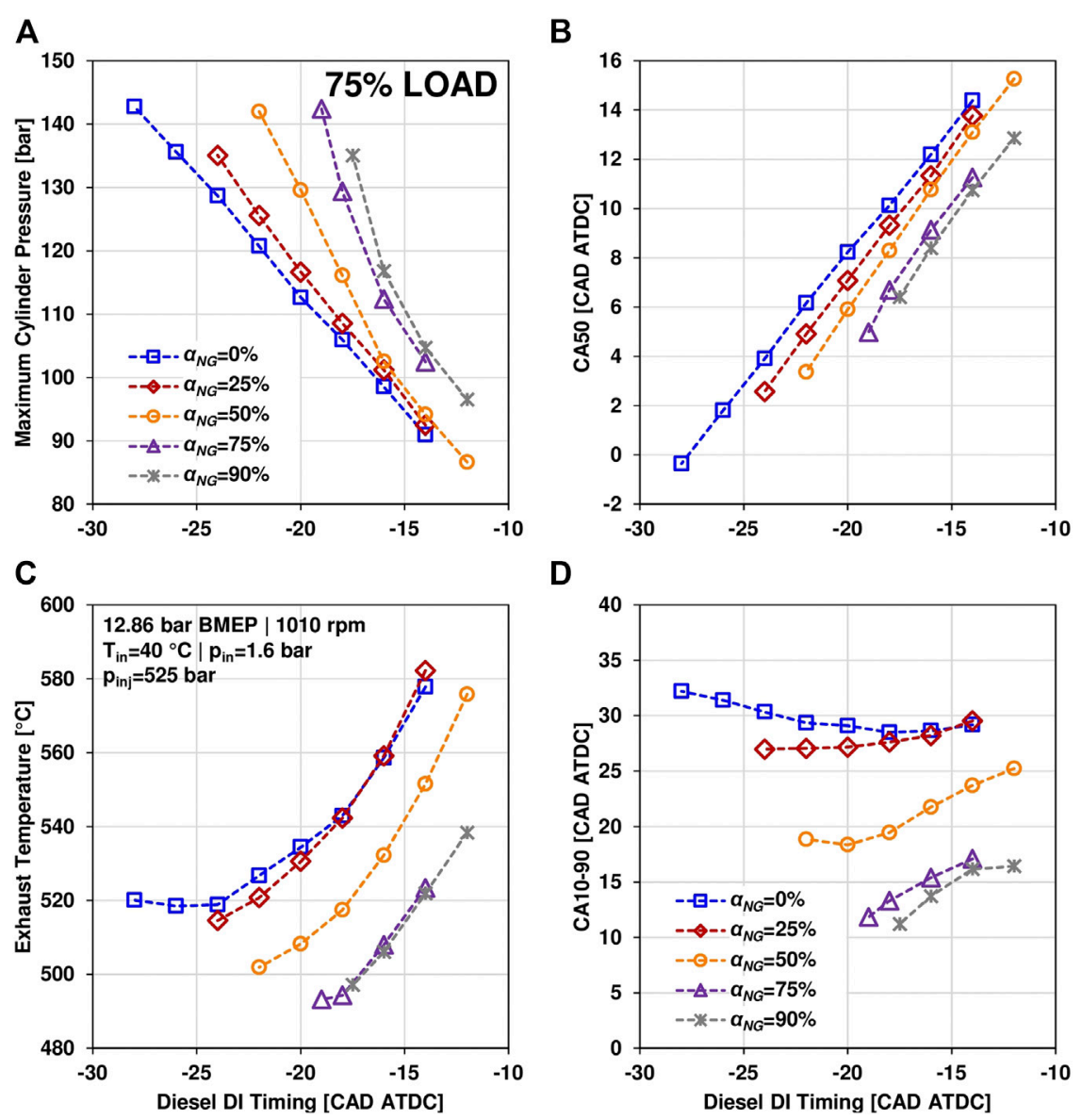

FIGURE 5 | 75\% load results-(A): Maximum cylinder pressure; (B): CA50; (C): Exhaust Temperature; (D): CA10-90.

and DI timings, the engine speed had to be increased to 1,120 rpm. The experimental conditions are listed in Table 2. The two variables for this stage of experiments were $\alpha_{\mathrm{NG}}$ and diesel DI timing (start of diesel injection).

All testing was conducted at steady state conditions without EGR. There are two main reasons for this. First, the purpose of this research was to isolate the effects of NG fraction and diesel DI timing which would be complicated by the profound effects of EGR on the combustion. Second, EGR control would typically be outside the scope of a simple conversion of a diesel engine to operate as an NG-diesel dual-fuel engine. However, the importance of EGR in optimizing NG-diesel combustion cannot be overstated and EGR effects have been evaluated in a separate study (Dev et al., 2020). The test procedure involved the following steps for each load condition. First, the engine motoring was started with the DC motor and a steady motoring speed of $600 \mathrm{rpm}$ was maintained. Next, the diesel DI was initiated to fire the engine. Fueling rate was controlled to maintain the idle speed of $600 \mathrm{rpm}$ and thereafter, the DC motor was disengaged. Subsequently, the engine load and speed were increased gradually to the target value using the dynamometer feedback. The engine was operated at the target load and speed for several minutes to reach steady conditions. Finally, the diesel DI timing was swept over a range. The limits of this range were based on the engine hardware. The timing advance limit was subject to constraints such as the peak pressure rise rate $(<12 \mathrm{bar} / \mathrm{CAD})$ and the peak cylinder pressure ( $<150$ bar). The timing retard limit was constrained by the exhaust temperature $\left(<600^{\circ} \mathrm{C}\right)$. For dual-fuel conditions, the diesel flow rate was gradually decreased and NG fueling rate was gradually increased to set the $\alpha_{\mathrm{NG}}$. Once the target $\alpha_{\mathrm{NG}}$ was reached, the diesel DI timing sweep was conducted similar to the diesel only case. The injection pressure of the diesel DI and intake temperature were maintained at 525 bar (denoted by " $p_{\text {inj }}$ ") and $40^{\circ} \mathrm{C}$ (denoted by " $\mathrm{T}_{\text {in }}$ "), respectively. The intake pressure (denoted by " $p_{\text {in }}$ ") and exhaust pressure (denoted by " $p_{e x}$ ") were constant for each load condition (Table 2). These values were set with the intention to keep the diesel baseline relative air/fuel ratio in the range of $\sim 1.5-1.7$ prevalent in high load operation in conventional diesel engines.

\section{RESULTS AND DISCUSSION}

This section is organized into three sub-sections. The combustion performance is described first, followed by the injector tip temperature and the emission results in the second and third sub-sections respectively. 

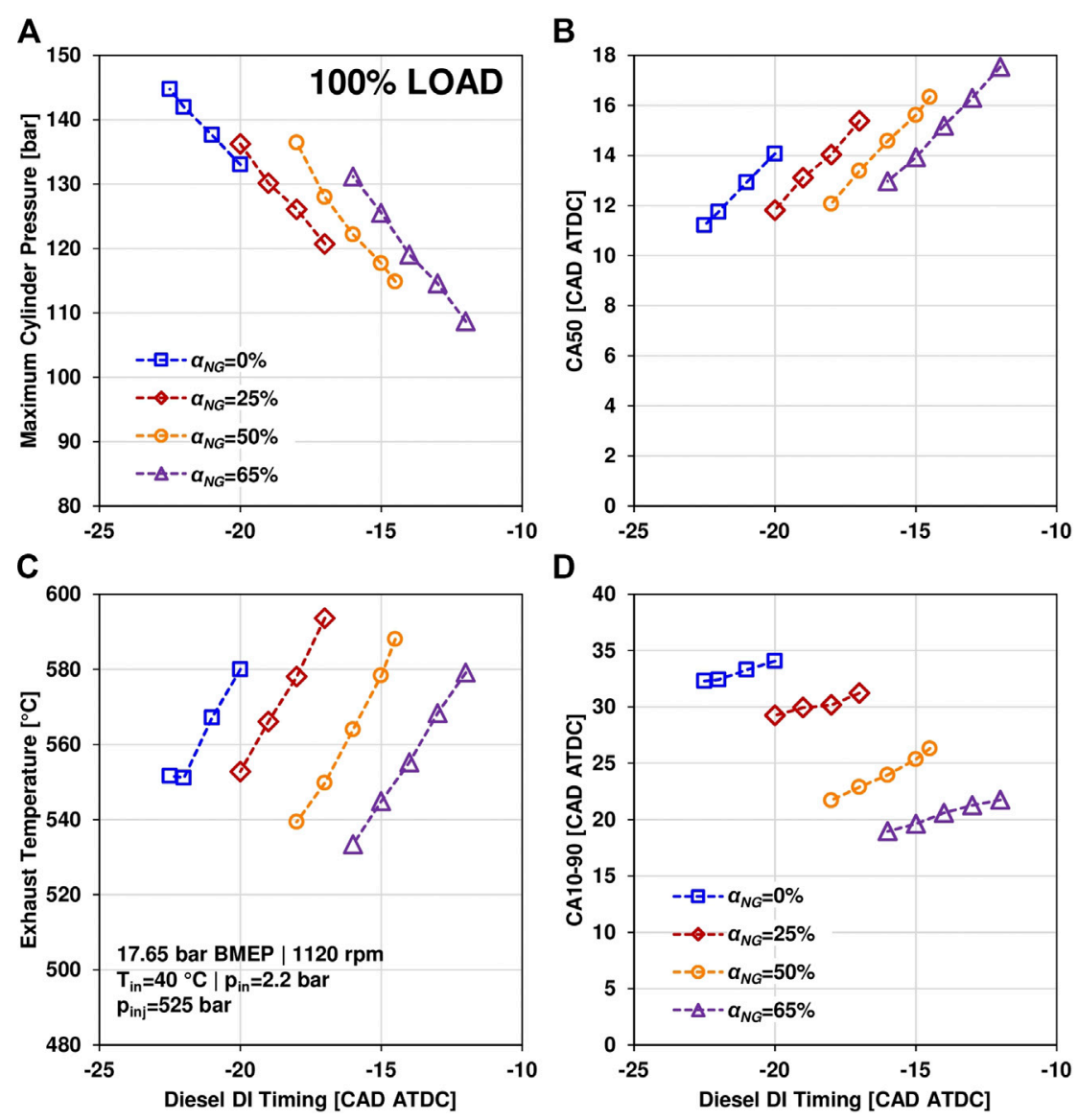

FIGURE 6 | 100\% load results-(A): Maximum cylinder pressure; (B): CA50; (C): Exhaust Temperature; (D): CA10-90.

\section{Combustion Performance}

The cylinder pressure and heat release rate traces for $75 \%$ of full load (BMEP $=12.86$ bar) are shown in Figure 3 at the diesel DI timing of -18 CAD after top dead center (ATDC) and different NG fractions. At each NG fraction, there are two major peaks on the net heat release rate curve. At $\alpha_{\mathrm{NG}}=0 \%$, the first peak of heat release corresponds to premixed combustion of air/diesel mixture, followed by the second major peak corresponding to the mixing controlled diffusion combustion. The second peak is followed by the relatively slower diffusion combustion of the remaining combustibles in the cylinder (beyond 15 CAD ATDC). For dual-fuel cases, increasing NG fraction causes the peak cylinder pressure and the peak heat release rate to increase. The first peak on the heat release rate curve of each NG fraction is related to premixed combustion of air/NG/diesel, followed by the diffusion combustion of remaining diesel and subsequent flame propagation of the background air/NG mixture. As the $\alpha_{\mathrm{NG}}$ increases, since the intake pressure is constant, the relative air/fuel ratio of the air/NG mixture decreases which in turn increases the flame propagation speed of the air/NG mixture. This can explain the sharp increase in the heat release rate of dual-fuel cases with respect to the diesel only case, and also causes an increase in the peak cylinder pressure. Additionally, as $\alpha_{\mathrm{NG}}$ increases, the late combustion (beyond 15
CAD ATDC) is minimized as well probably due to the increased flame propagation speed of the background mixture.

At the full load condition (BMEP $=17.65$ bar), owing to the hardware limitations of exhaust temperature and peak pressure, there were limited overlaps in the DI timing sweeps. Therefore, the pressure and heat release traces are shown at $\alpha_{\mathrm{NG}}=0 \%$ and $\alpha_{\mathrm{NG}}=65 \%$ at an advanced and a retarded diesel DI timing (Figure 4). Advancing timing causes the peak cylinder pressure and peak heat release rate to increase for both diesel and dual-fuel cases. The peak of the heat release rate is advanced as well since the combustion is initiated earlier. Since the dualfuel DI timing is significantly retarded owing to the higher peak pressure rise rate and maximum cylinder pressure compared to diesel only case, the peak cylinder pressure is lower. Again, similar to the $75 \%$ load case, the dual-fuel combustion mechanism can cause the peak heat release rate of $\alpha_{\mathrm{NG}}=65 \%$ cases to be higher than the diesel cases due to increased flame propagation speed of air/NG mixture.

The maximum cylinder pressure, exhaust temperature, CA50 and CA10-90 at 75\% load are shown in Figure 5. This figure also highlights the constraints for advancing and retarding the DI timing explained in the previous section. For all $\alpha_{\mathrm{NG}}$, advancing injection timing causes the maximum cylinder pressure to increase, CA50 to advance and the exhaust temperature to 
A

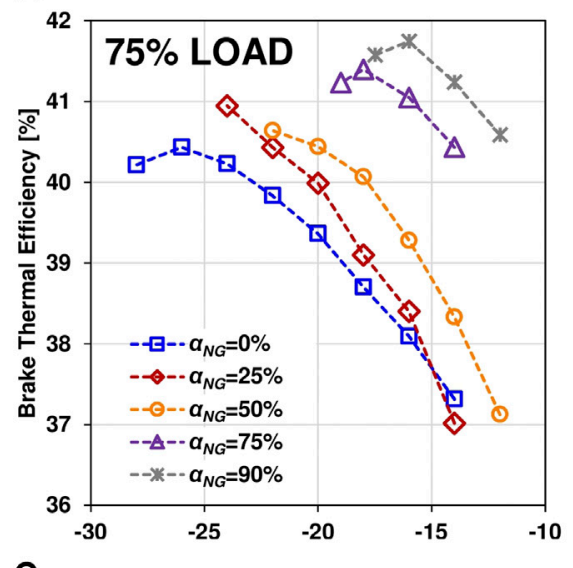

C

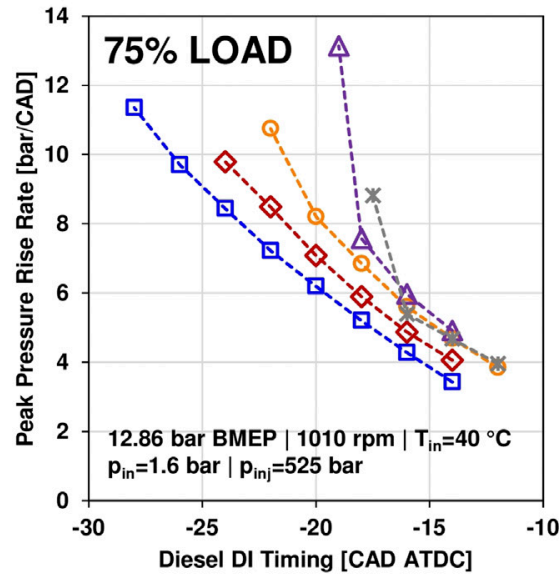

B
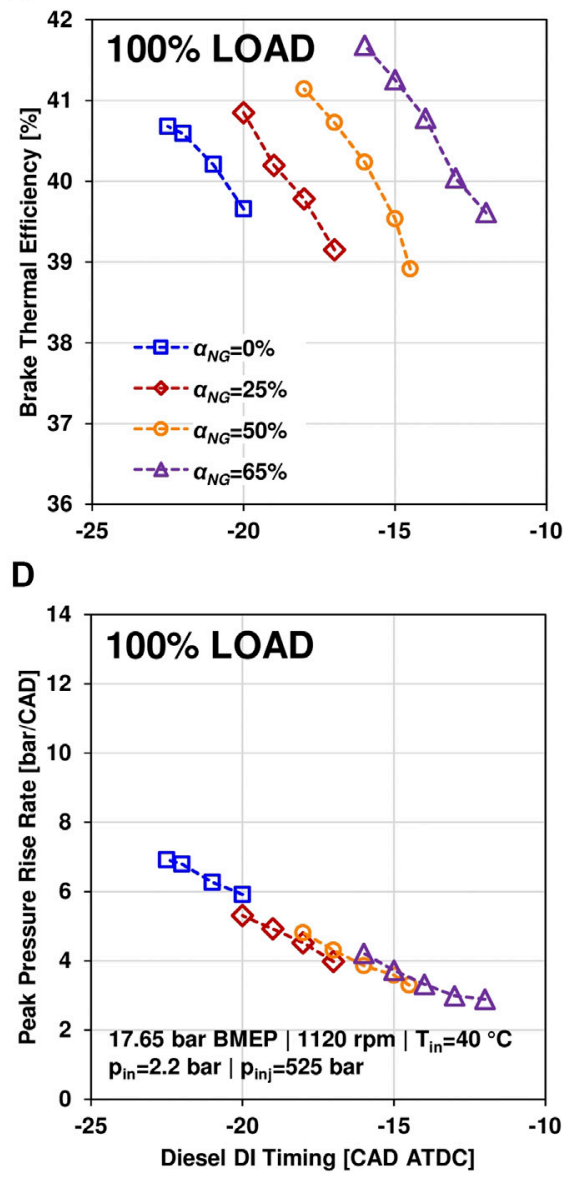

FIGURE 7 | (A). BTE at 75\% load; (B). BTE at 100\% load; (C). Peak pressure rise rate at 75\% load; (D). Peak pressure rise rate at 100\% load.
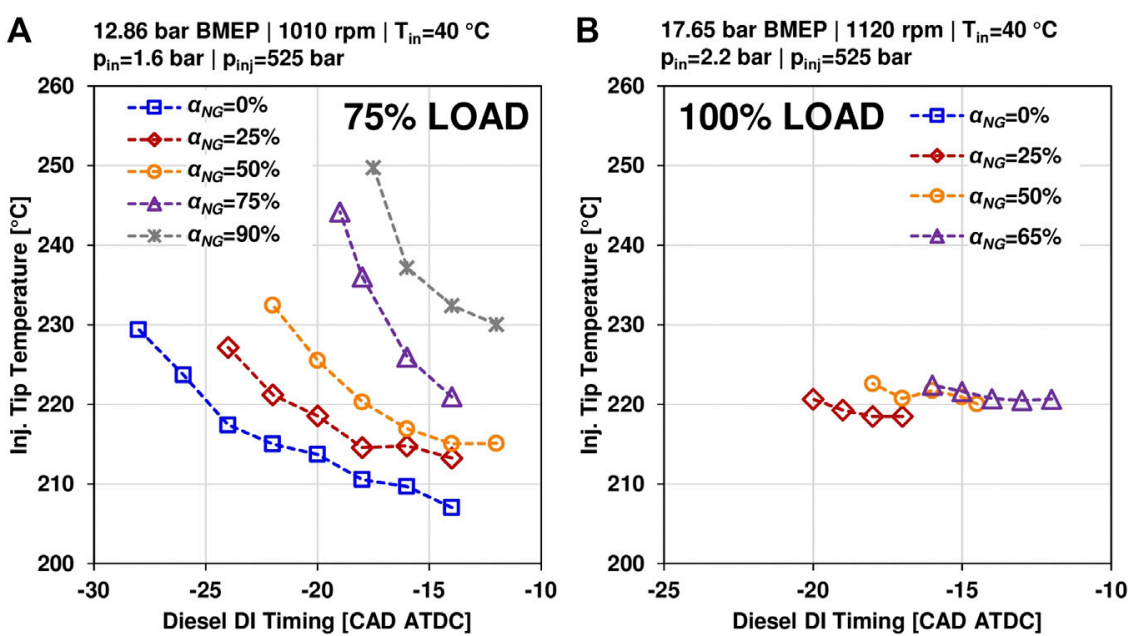

FIGURE 8 | Injector tip temperature-(A). 75\% load; (B). 100\% load. 
decrease. When combustion is initiated earlier during the compression stroke with an advanced DI timing, more heat is released near top dead center, causing the cylinder pressure to be higher. When the injection timing is retarded, a greater portion of fuel energy is released later into the expansion stroke, which causes the exhaust temperature to increase. For $\alpha_{\mathrm{NG}}=0 \%$, retarding timing causes the combustion duration (CA10-90) to decrease as more fuel is injected later into the compression stroke when temperature is higher. This can enhance the combustion rate. However, excessive retardation can cause the CA50 to be late (beyond 10 CAD ATDC), which may reduce the combustion efficiency. Consequently, the CA10-90 may start to increase again. For dual-fuel cases, retarding the DI timing tends to increase the combustion duration. An earlier injection timing may allow part of the diesel injection to mix with the air/NG background thereby increasing the reactivity of the background air/NG mixture. This may enhance the rate of the flame propagation that follows.

With increasing $\alpha_{\mathrm{NG}}$, at the same DI timing, the maximum cylinder pressure increases, the exhaust temperature decreases, the CA50 is advanced, and the CA10-90 is shorter. The increase in the maximum cylinder pressure can be correlated with the advance in CA50. As explained previously, this phenomenon can be due to the shift of the combustion from conventional diesel's primarily diffusion combustion to premixed type of combustion with increasing $\alpha_{\mathrm{NG}}$. The lower exhaust temperature with increasing $\alpha_{\mathrm{NG}}$ at constant DI timing could be due to the advanced CA50.

At the $100 \%$ load condition (Figure 6), the overall trends are similar to those at $75 \%$ load with one exception. For $\alpha_{\mathrm{NG}}=0 \%$, retarding the injection timing increases the combustion duration probably due to the retardation of the combustion phasing (CA50, Figure 6) beyond 11 CAD ATDC.

Advancing the DI timing can be advantageous in terms of increasing the BTE at both load levels (Figure 7). This is probably due to the optimization of the CA50. When the CA50 is too advanced, the energy release from the fuel combustion could be working against the engine compression. When the CA50 is too retarded, the energy release may be too late to derive useful mechanical work. Therefore, for $\alpha_{\mathrm{NG}}=0 \%$ at $75 \%$ load, the BTE increases with advancing DI timing, but then starts to decrease at the most advanced timing which corresponds to a CA50 that is too close to the TDC. Similar peaks of BTE are observed for other $\alpha_{\mathrm{NG}}$ cases as well. Increasing $\alpha_{\mathrm{NG}}$ can cause the BTE to increase for both load levels since the CA50 is advanced to a more optimal range, the combustion efficiency is improved with the enhanced reactivity of the background air/NG mixture, and combustion duration is shorter, which causes more heat to be released near the TDC. The highest BTE can be in the range of around $42 \%$ at the NG fractions of $90 \%$ and $65 \%$ for the $75 \%$ and $100 \%$ load conditions, respectively.

The DI timing advance is subject to an additional hardware constraint of peak pressure rise rate (Figure 7). The peak pressure rise rate tends to increase with the advance in the CA50 either through the advance of DI timing or the increase of $\alpha_{\mathrm{NG}}$. Therefore, peak pressure rise rates of $75 \%$ load cases are greater than those of $100 \%$ load cases because of retarded CA50.

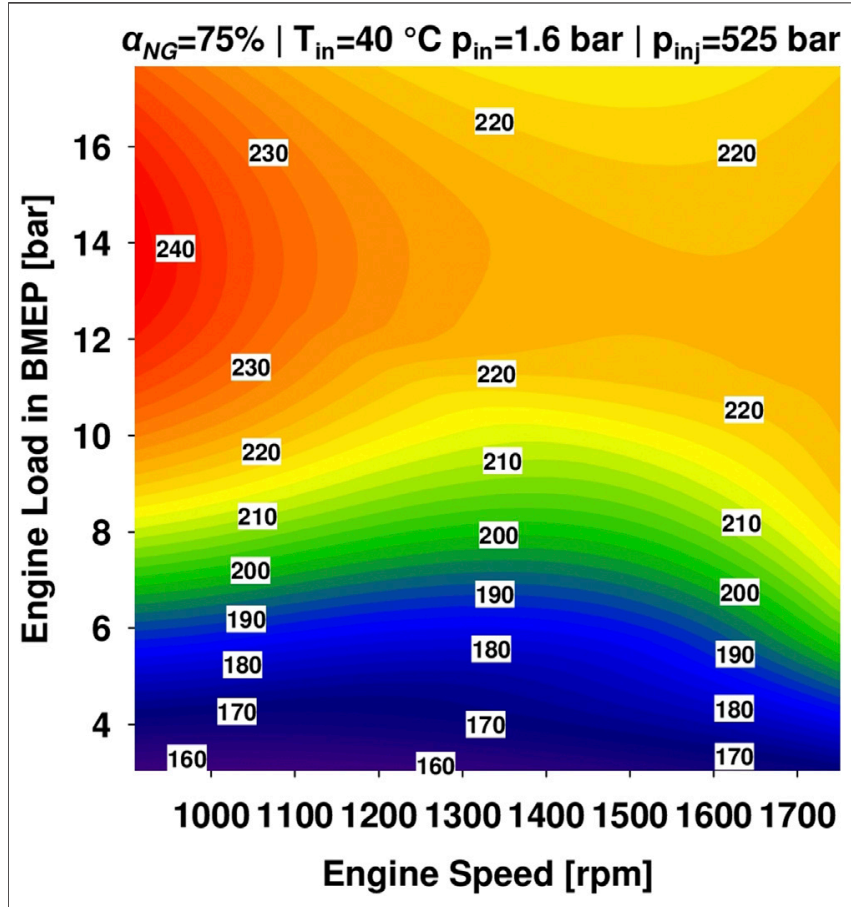

FIGURE 9 | Load-speed map of injection tip temperature at natural gas fraction of $75 \%$.

\section{Injector Tip Temperature}

The injector tip temperature at $75 \%$ and $100 \%$ loads are shown in Figure 8. The injector tip temperature is expected to be correlated to the average cylinder temperature during each cycle. However, the range of in-cylinder temperature during a cycle is usually quite wide. At $75 \%$ load, as the DI timing is advanced, the injector tip temperature increases probably due to the increased heat release near the TDC and therefore higher cylinder temperature. This is further supported by the fact that the injector tip temperature keeps increasing even though the BTE decreases with advancing DI timing, since the most advanced CA50 approaches the TDC. With increasing $\alpha_{\mathrm{NG}}$, the injector tip temperature keeps increasing. This is because of the decrease in diesel flow rate and increase in the in-cylinder temperature. The decrease in diesel flow rate reduces the cooling effect, and the increase in the peak cylinder pressure (Figure 5) increases the cylinder temperature. At $75 \%$ load, the maximum observed injector tip temperature is $\sim 250^{\circ} \mathrm{C}$.

At $100 \%$ load, data of injector tip temperature was not available for $\alpha_{\mathrm{NG}}=0 \%$. However, the dual-fuel cases are shown in Figure 8. While the general trends for $100 \%$ load are similar to those for $75 \%$ load, the range of injector tip temperatures is much narrower at $\sim 220^{\circ} \mathrm{C}$. This is probably due to the delayed CA50 for the $100 \%$ load cases.

For all test conditions, the injector tip temperatures were lower than the critical temperature for coking to occur inside the injector (Argueyrolles et al., 2007). The authors' laboratory has previously conducted a detailed load-speed analysis of the injector tip temperature at $\alpha_{\mathrm{NG}}=75 \%$ (Figure 9). For this test 

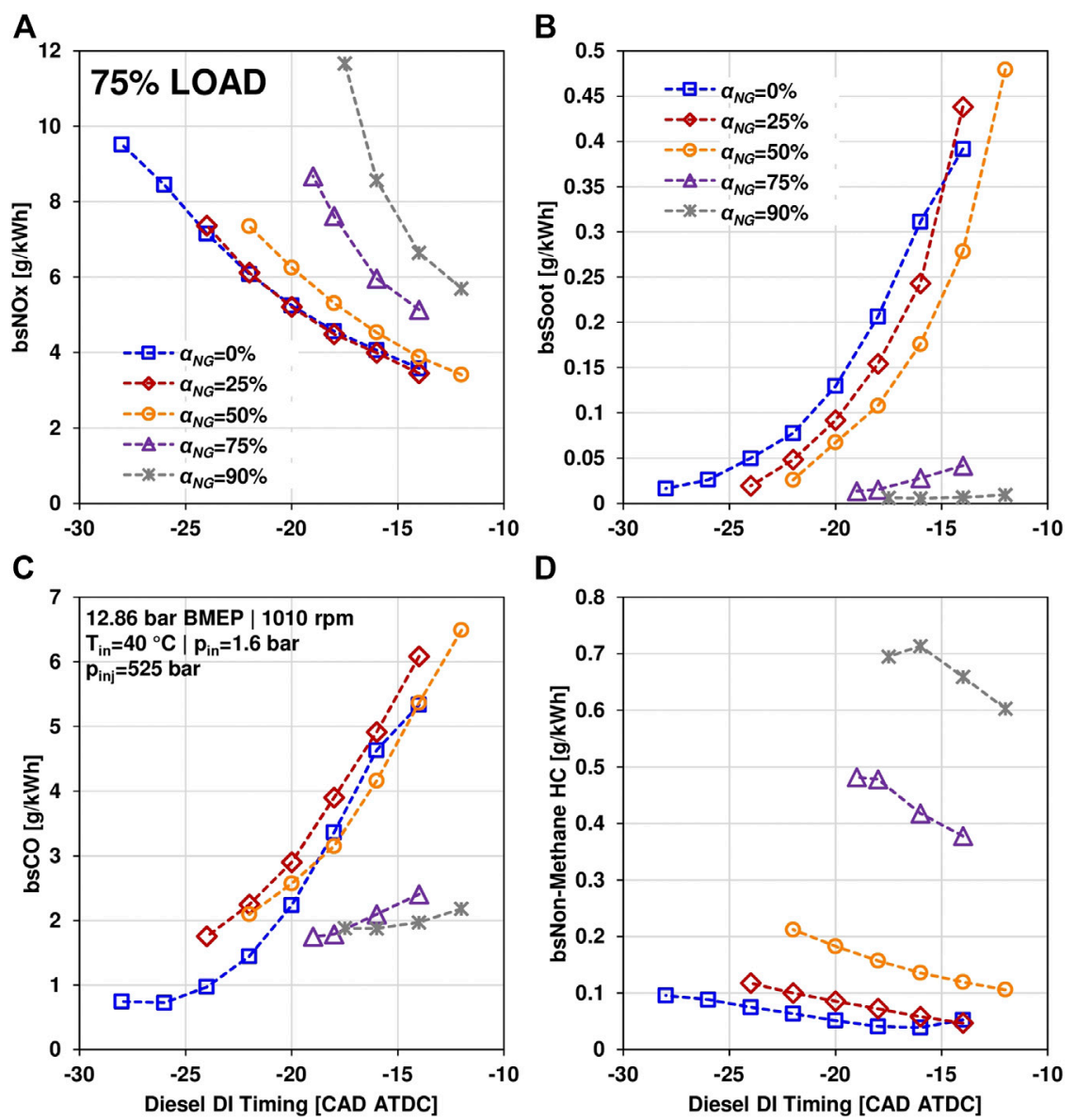

FIGURE 10 | Exhaust emissions at 75\% load-(A). NOx; (B). Soot; (C). CO; (D). Non-methane HC.
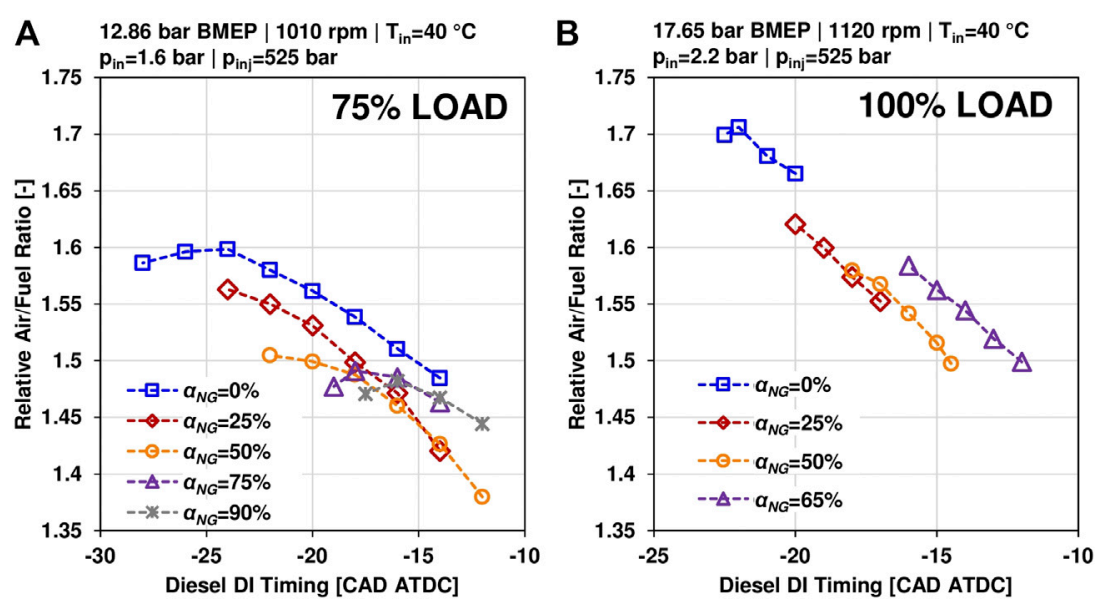

FIGURE 11 | Relative air/fuel ratio-(A). 75\% load; (B). 100\% load.

setup, the maximum injector tip temperatures are observed in the load range of 12-15 bar BMEP due to the combined effects of high fuel energy input and DI timing (Guo and Liko, 2018).

\section{Emissions}

NOx, soot, CO and non-methane total hydrocarbons (HCs) are some of the primary regulated emissions for diesel engines used 

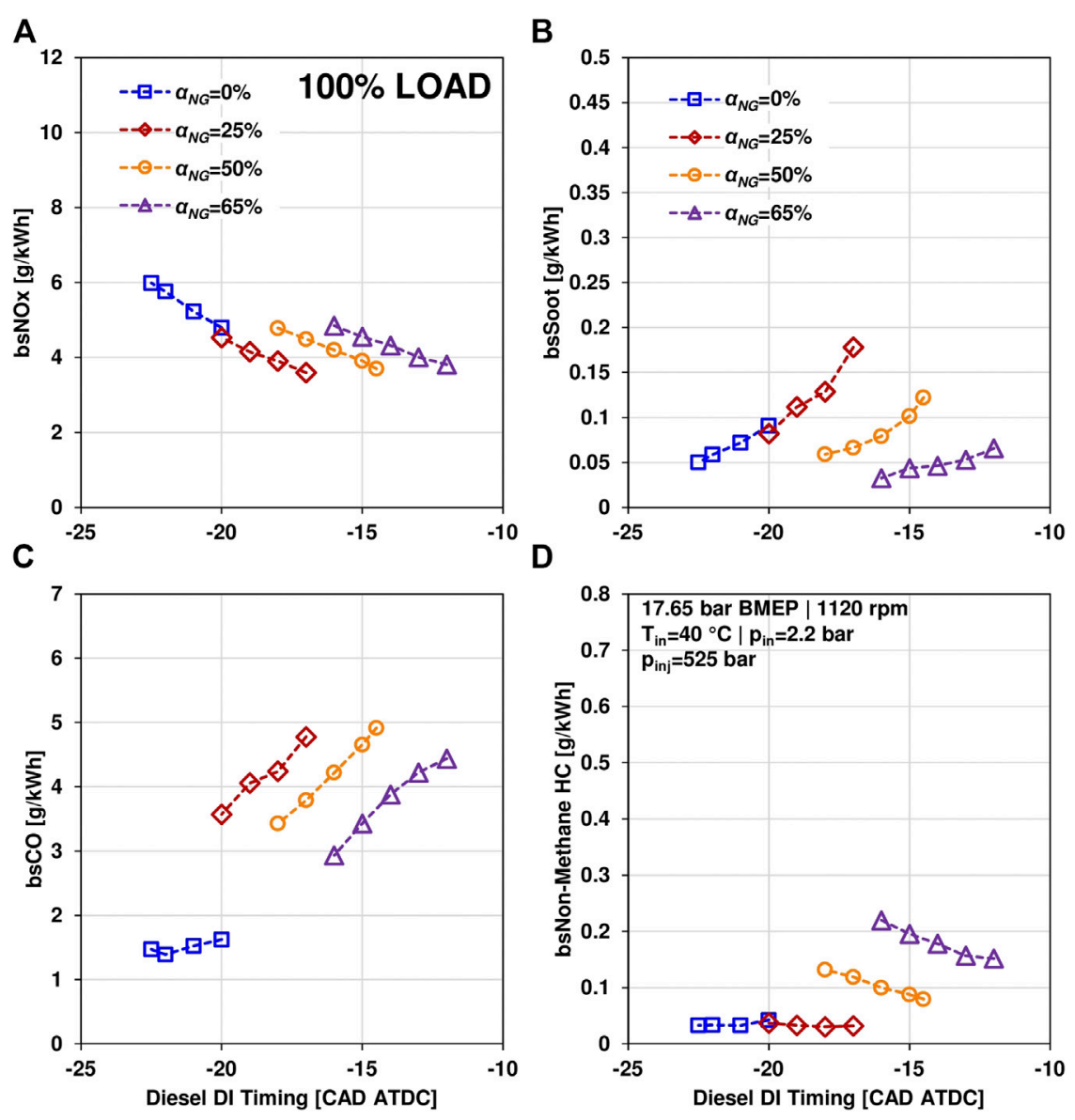

FIGURE 12 | Exhaust emissions at 100\% load-(A). NOx; (B). Soot; (C). CO; (D). Non-methane HC.

in the transportation sector. Figure 10 shows the brake specific emissions of the test cases at $75 \%$ load (denoted by "bs" prefix). NOx formation is primarily dependent on the in-cylinder temperature. Generally, at a particular NG fraction and DI timing, the maximum cylinder pressure and the maximum cylinder temperature would be directly correlated. It is noted from Figure 10 that NOx emissions generally decrease with retarding DI timing. This is because the CA50 is further away from the TDC, which in turn reduces the peak cylinder temperature. The NOx emissions of $\alpha_{\mathrm{NG}}=0 \%$ and $\alpha_{\mathrm{NG}}=25 \%$ are similar probably due to combined effects of NOx formation mechanism and in-cylinder temperature. The prompt route and thermal route are the two primary NOx formation mechanisms in most combustion chambers. The prompt route plays a significant role in NOx formation of a diffusion combustion process in which nitric oxide (NO) can be formed due to the initial reactions of hydrocarbon radicals with nitrogen (Miller and Bowman, 1989). The thermal route dominates NOx formation in most premixed combustion processes (Guo et al., 2005) due to the oxidation of nitrogen in high temperature combustion and post combustion zones (Miller and Bowman, 1989). With increasing NG fraction for a dual-fuel engine, the diffusion fraction inside the cylinder decreases, which tends to reduce NOx formation by the prompt route. However, the increase in NG fraction leads to higher cylinder pressure and temperature, as discussed above, which tends to increase NOx formation by the thermal route. The combined variations in NOx formation from the prompt and thermal routes results in the negligible change in NOx emissions when NG fraction increases from zero to 25. For $\alpha_{\mathrm{NG}}=50 \%$ and higher, the increase in NOx formation due to the thermal route is greater than the decrease in NOx formation by the prompt route, which causes the increase in NOx emissions with increasing NG fraction. This may also reduce the impact of the change in the specific heat capacity of the air-NG mixture with change in the NG fraction as reported in literature (Imran et al., 2014).

Soot tends to form in the in-cylinder regions where the temperature is high and the air-fuel mixture is rich (Dec, 1997; Dec, 2009). When the DI timing is retarded, diesel is injected later in the compression stroke when the temperature is higher and time period available for the diesel to mix with the air/NG background and form a homogenous mixture is limited. This can cause the soot emissions to increase when the DI timing is retarded. With increasing $\alpha_{\mathrm{NG}}$, as the injected diesel quantity decreases, premixed combustion is predominant. Consequently, the soot formation rate can be reduced (Figure 10). While the advantage of dual-fuel combustion in terms of soot reduction is 

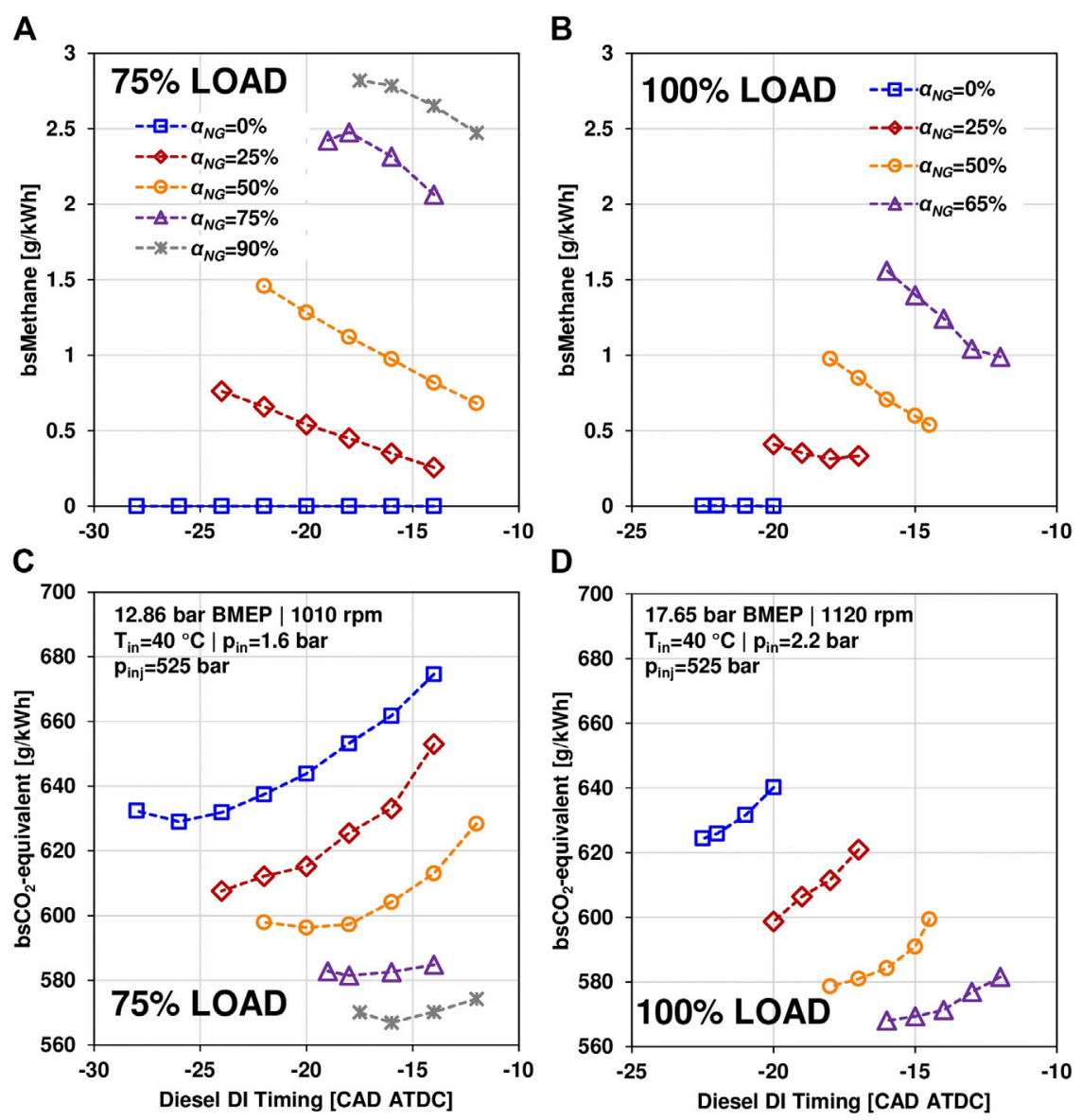

FIGURE 13 | (A). Methane emissions at 75\% load; (B). Methane emissions at 100\% load; (C). $\mathrm{CO}_{2}$-equivalent emissions at $75 \%$ load; (D). CO ${ }_{2}$-equivalent emissions at $100 \%$ load.

well established (Wei and Geng, 2016), it is also observed that at very high $\alpha_{\mathrm{NG}}(75 \%$ and above), owing to the reduced diesel injection quantity, the impact of DI timing on the soot emissions is reduced. The lowest soot emissions observed are of the order of $0.01 \mathrm{~g} / \mathrm{kWh}$ when engine-out NOx emissions are below $6 \mathrm{~g} / \mathrm{kWh}$ for $\alpha_{\mathrm{NG}}=90 \%$ at $75 \%$ load. Past research on PM speciation of NG-diesel dual-fuel engines has shown that unlike diesel engines, the majority of PM fraction is volatile in nature rather than elemental carbon (Mustafi et al., 2010). Additionally, there are differences in the shape of the PM agglomerates and their fractal dimensions between diesel and dual-fuel operation (Mustafi et al., 2009). The NG fraction can also have an impact on the PM size distribution and volatile mass fraction (Momenimovahed et al., 2019). The present analysis is limited to soot and does not account for the volatile PM. Moreover, these soot emissions tend to originate from the diesel fuel (Graves et al., 2015).

The CO emissions for the $75 \%$ load cases are shown in Figure 10 as well. CO typically originates from the incomplete combustion of hydrocarbons. With DI timing retard, the CO emissions increase. The BTE decreases with DI timing retardation. Therefore, as the fueling rate is increased to maintain the load, the relative air/fuel ratio decreases thereby reducing the oxygen availability (Figure 11). Moreover, a delayed DI timing can reduce the time available for diesel to mix with the air/NG background. These two factors can decrease the probability of $\mathrm{CO}$ oxidation. With increasing $\alpha_{\mathrm{NG}}$, the $\mathrm{CO}$ emissions tend to increase and then decrease. There are two points to consider with increasing $\alpha_{\mathrm{NG}}$. First, the background air/ fuel ratio of the air/NG mixture is decreased and second, the flame propagation speed is increased (evidenced by shorter combustion duration (Figure 5). The first and second actions can work against each other to increase or decrease $\mathrm{CO}$ formation rates respectively. For $\alpha_{\mathrm{NG}}<75 \%$, the reduction in the air/fuel ratio may be balanced by the increase in the flame propagation speed which can cause the $\mathrm{CO}$ emissions to remain similar. With further increase in $\alpha_{\mathrm{NG}}$, majority of the fuel is NG and the flame propagation speed is higher. NG can form a homogenous mixture with air while the diesel fuel quantity is significantly reduced (diesel flow rate decreases from $\sim 5.7$ to $\sim 1.26 \mathrm{~kg} / \mathrm{h}$ ). This may explain the $\mathrm{CO}$ trend with change in $\alpha_{\mathrm{NG}}$.

The non-methane HC emissions are also shown in Figure 10. When the $a_{N G}$ is increased, the non-methane $\mathrm{HC}$ emissions increase. With increasing $a_{N G}$, while the reactivity of the air/ NG background mixture may increase, more HC molecules (from $\mathrm{NG)}$ may make their way into the crevice volumes and remain 
unburnt. When the DI timing is retarded, the non-methane HC emissions decrease. This may be due to the delayed combustion and higher temperatures during the expansion stroke which may enhance the combustion of the charge trapped in the crevices.

At $100 \%$ load, the emission trends are qualitatively similar to those at $75 \%$ load (Figure 12). There are other exceptions, however. The specific NOx emissions for $100 \%$ load cases are lower than the $75 \%$ load cases probably due to the retarded CA50 and to a small extent, the higher load. There is slight reduction in the NOx emissions for the dual-fuel cases in comparison to diesel. This could be due to the DI timing retardation necessary to limit the peak cylinder pressure which counters the reduction in CA10-90 as more NG is used. Soot emissions for the diesel case are less than $0.1 \mathrm{~g} / \mathrm{kWh}$, and for $\alpha_{\mathrm{NG}}=25 \%$, soot emissions tend to increase. The relative air/fuel ratio can decrease from 1.65 for $\alpha_{\mathrm{NG}}=0 \%$ to 1.55 for $\alpha_{\mathrm{NG}}=25 \%$ which can cause the increase in the soot emissions (Figure 11). Further increase in $\alpha_{N G}$ allows the diesel flow rate to be decreased significantly and premixed combustion is predominant, leading to reduced soot formation.

While non-methane $\mathrm{HC}$ trends with increase in $\alpha_{\mathrm{NG}}$ are similar for the $75 \%$ and $100 \%$ load levels, the CO emission trends are different (Figure 12). When NG is used, the CO emissions increase. At $100 \%$ load, though the diesel flow rate can be decreased with increasing $\alpha_{\mathrm{NG}}$, it is still significant $(2.7 \mathrm{~kg} / \mathrm{h})$ even at the highest $\alpha_{\mathrm{NG}}=65 \%$. Therefore, the richer air/NG background effect explained previously can reduce oxygen availability especially when the DI timing is retarded. At a similar DI timing for instance of -18 CAD ATDC, CO emissions are lower with increasing $\alpha_{\mathrm{NG}}$ and the trend is analogous to the $75 \%$ load cases.

One of the main objectives of developing diesel-NG dual-fuel engines is the reduction in GHG emissions. Figure $\mathbf{1 3}$ shows the methane emissions and $\mathrm{CO}_{2}$-equivalent emissions at $75 \%$ and $100 \%$ load. The trends are similar for both load levels with respect to DI timing and $\alpha_{\mathrm{NG}}$. Methane emissions increase with increasing $\alpha_{N G}$ probably due to higher number of methane molecules trapped in the crevice and boundary regions. With retarding DI timing, the reduced cylinder pressure leads to less methane trapped in crevice and boundary regions.

The $\mathrm{CO}_{2}$-equivalent emissions are calculated based on the $\mathrm{CO}_{2}$ and methane emissions (Figure 13). Methane is a more potent GHG than $\mathrm{CO}_{2}$, and a weightage of 25 is included in the $\mathrm{CO}_{2}$-equivalent calculation. Regardless of the higher methane emissions from dual-fuel cases, it is found that increasing $\alpha_{\mathrm{NG}}$ can reduce the $\mathrm{CO}_{2}$-equivalent emissions at both load conditions. Advanced DI timings which correspond to the highest BTEs typically have the lowest $\mathrm{CO}_{2}$-equivalent emissions.

\section{CONCLUSIONS}

A study on the effects of DI timing and increasing NG fraction on diesel-NG dual-fuel combustion is conducted on a heavy-duty engine setup. Injector tip temperature is measured using a specially modified injector. Combustion performance and exhaust emissions are studied as well. Tests are conducted at
$75 \%$ and $100 \%$ load at the lower range of engine speeds. The main conclusions of this research are

- Combustion phasing (CA50) is a very critical determinant of dual-fuel combustion performance at high engine loads. Increasing NG fraction can advance the CA50 and cause the combustion duration to decrease. Using an optimized CA50 obtained through control of the DI timing, brake thermal efficiencies of the order of $\sim 42 \%$ can be achieved.

- At high loads, advanced diesel DI timings typically correspond to the higher maximum cylinder pressure, maximum pressure rise rate, $\mathrm{NOx}$ emissions, lower soot and $\mathrm{CO}$ emissions, and higher $\mathrm{BTE}$ and lower $\mathrm{CO}_{2}$ equivalent emissions.

- With increasing NG fraction at a given DI timing, injector tip temperature increases. With advancing DI timing at a given NG fraction, injector tip temperature increases as well. At all the test conditions, injector tip temperature does not exceed $250^{\circ} \mathrm{C}$. This is lower than the temperature threshold of $300^{\circ} \mathrm{C}$ beyond which injector coking issues could be exacerbated.

- CO emissions tend to decrease and HC emissions (methane and non-methane) tend to increase with increase in the NG fraction at a given DI timing.

- At high loads, increasing NG fraction can increase the methane emissions. However, the $\mathrm{CO}_{2}$-equivalent emissions decrease with increasing $\mathrm{NG}$ fraction.

\section{DATA AVAILABILITY STATEMENT}

The raw data supporting the conclusions of this article will be made available by the authors, without undue reservation.

\section{AUTHOR CONTRIBUTIONS}

SD processed the data, made the figures and wrote the manuscript. HG collected and processed the data, and also edited the manuscript. BL conducted the tests and organized the raw data.

\section{FUNDING}

Funding for this work was provided by Natural Resources Canada through the PERD Energy End Use (Project 3B03.003) and National Research Council of Canada through the internal Bioenergy program.

\section{SUPPLEMENTARY MATERIAL}

The Supplementary Material for this article can be found online at: https://www.frontiersin.org/articles/10.3389/fmech.2020.545416/ full\#supplementary-material. 


\section{REFERENCES}

Argueyrolles, B., Dehoux, S., Gastaldi, P., Grosjean, L., Levy, F., Michel, A., et al. (2007). Influence of injector nozzle design and cavitation on coking phenomenon. SAE Technical Paper No. 2007-01-1896.

Christian, V. R., Knopf, F., Jaschek, A., and Schindler, W. (1993). Eine neue Messmethodik der Bosch-Zahl mit erhohter Empfindlichkeit. Motortech Z. 54, 16-22.

Dec, J. E. (1997). A conceptual model of DL diesel combustion based on laser-sheet imaging. SAE Trans. 1319-1348. doi:10.4271/970873

Dec, J. E. (2009). Advanced compression-ignition engines-understanding the incylinder processes. Proc. Combust. Inst. 32 (2), 2727-2742. doi:10.1016/j.proci. 2008.08.008

Dev, S., Guo, H., Lafrance, S., and Liko, B. (2020). An experimental study on the effect of exhaust gas recirculation on a natural gas-diesel dual-fuel engine. SAE Technical Paper 2020-01-0310.

Figer, G., Seitz, H. F., Graf, G., and Schreier, H. (2014). Commercial vehicle natural gas engines with diesel efficiency. MTZWorldwide. 75 (10), 10-15. doi:10.1007/ s38313-014-0229-2

Gärtner, U., Rabl, H.-P., and Zink, U. (2018). Exhaust gas aftertreatment of the future. MTZ Worldwide. 79, 70-75. doi:10.1007/s38313-018-0060-2

Government of Canada (2019). Clean fuel standard. Available at: https://www. canada.ca/en/environment-climate-change/services/managing-pollution/energyproduction/fuel-regulations/clean-fuel-standard.html (Accessed March 07, 2020).

Government of Canada (2016). The Paris agreement. Available at: https://www.canada. $\mathrm{ca} / \mathrm{en} /$ environment-climate-change/services/climate-change/paris-agreement.html (Accessed March 07, 2020).

Graves, B., Olfert, J., Patychuk, B., Dastanpour, R., and Rogak, S. (2015). Characterization of particulate matter morphology and volatility from a compression-ignition natural-gas direct-injection engine. Aerosol. Sci. Technol. 49 (8), 589-598. doi:10.1080/02786826.2015.1050482

Guo, H., and Liko, B. (2018). "Injector tip temperature and combustion performance of a natural gas-diesel dual fuel engine at medium and high load conditions," in Proceedings of the ASME 2018 internal combustion engine division fall technical conference. American Society of Mechanical Engineers Digital Collection, San Diego, CA, November 2018.

Guo, H., Liko, B., and Neill, W. S. (2017). "Effect of diesel injection split on combustion and emissions performance of a natural gas-diesel dual fuel engine at a low load condition," in Proceedings of the ASME 2017 internal combustion engine division fall technical conference. American Society of Mechanical Engineers Digital Collection, Seattle, WC, October 2017.

Guo, H., Liu, F., and Smallwood, G. J. (2005). A numerical study on NOx formation in laminar counterflow $\mathrm{CH}_{4} /$ air triple flames. Combust. Flame. 143 (3), 282-298. doi:10.1016/j.combustflame.2005.06.004

Guo, H., Neill, W. S., and Liko, B. (2015). “An experimental investigation on the combustion and emissions performance of a natural gas-diesel dual fuel engine at low and medium loads," in Proceedings of the ASME 2015 internal combustion engine division fall technical conference. American Society of Mechanical Engineers Digital Collection, Houston, TX, November 2015.

Imran, S., Emberson, D. R., Diez, A., Wen, D. S., Crookes, R. J., and Korakianitis, T. (2014). Natural gas fueled compression ignition engine performance and emissions maps with diesel and RME pilot fuels. Appl. Energy. 124, 354-365. doi:10.1016/j.apenergy.2014.02.067

Karim, G. A. (1980). A review of combustion processes in the dual fuel engine-the gas diesel engine. Prog. Energy Combust. Sci. 6 (3), 277-285. doi:10.1016/03601285(80)90019-2

Königsson, F., Stalhammar, P., and Angstrom, H. E. (2012). Controlling the injector tip temperature in a diesel dual fuel engine. SAE Technical Paper No. 2012-01-0826.

Li, Y., Li, H., and Guo, H. (2018). A numerical investigation on $\mathrm{NO}_{2}$ formation reaction pathway in a natural gas-diesel dual fuel engine. Combust. Flame. 190, 337-348. doi:10.1016/j.combustflame.2017.12.006

Liu, J., Yang, F., Wang, H., Ouyang, M., and Hao, S. (2013). Effects of pilot fuel quantity on the emissions characteristics of a CNG/diesel dual fuel engine with optimized pilot injection timing. Appl. Energy. 110, 201-206. doi:10.1016/j. apenergy.2013.03.024

Miller, J. A., and Bowman, C. T. (1989). Mechanism and modeling of nitrogen chemistry in combustion. Prog. Energy Combust. Sci. 15 (4), 287-338. doi:10. 1016/0360-1285(89)90017-8

Momenimovahed, A., Liu, F., Thomson, K. A., Smallwood, G. J., and Guo, H. (2019). Effect of fuel composition on properties of particles emitted from a diesel-natural gas dual fuel engine. Int. J. Engine Res. doi:10.1177/ 1468087419846018

Mustafi, N. N., and Raine, R. R. (2009). Electron microscopy investigation of particulate matter from a dual fuel engine. Aerosol. Sci. Technol. 43 (9), 951-960. doi:10.1080/02786820903067210

Mustafi, N. N., Raine, R. R., and James, B. (2010). Characterization of exhaust particulates from a dual fuel engine by TGA, XPS, and Raman techniques. Aerosol. Sci. Technol. 44 (11), 954-963. doi:10.1080/02786826.2010.503668

Osman, A. I., Abu-Dahrieh, J. K., Laffir, F., Curtin, T., Thompson, J. M., and Rooney, D. W. (2016). A bimetallic catalyst on a dual component support for low temperature total methane oxidation. Appl. Catal. B Environ. 187, 408-418. doi:10.1016/j.apcatb.2016.01.017

Papagiannakis, R. G., and Hountalas, D. T. (2003). Experimental investigation concerning the effect of natural gas percentage on performance and emissions of a DI dual fuel diesel engine. Appl. Therm. Eng. 23 (3), 353-365. doi:10.1016/ S1359-4311(02)00187-4

Papagiannakis, R. G., Rakopoulos, C. D., Hountalas, D. T., and Rakopoulos, D. C. (2010). Emission characteristics of high speed, dual fuel, compression ignition engine operating in a wide range of natural gas/diesel fuel proportions. Fuel. 89 (7), 1397-1406. doi:10.1016/j.fuel.2009.11.001

Sahoo, B. B., Sahoo, N., and Saha, U. K. (2009). Effect of engine parameters and type of gaseous fuel on the performance of dual-fuel gas diesel engines-a critical review. Renew. Sustain. Energy Rev. 13 (6-7), 1151-1184. doi:10.1016/j. rser.2008.08.003

Sharpe, B. (2019). Zero-emission tractor-trailers in Canada. ICCT working paper. . Srinivasan, K. K., Krishnan, S. R., Singh, S., Midkiff, K. C., Bell, S. R., Gong, W., et al. (2006). The advanced injection low pilot ignited natural gas engine: a combustion analysis. ASME. J. Eng. Gas Turbines Power. 128 (1), 213-218. doi: $10.1115 / 1.1915428$

United States Environmental Protection Agency (2020). Overview of greenhouse gases. Available at: https://www.epa.gov/ghgemissions/overview-greenhousegases (Accessed February 15, 2020).

Wagemakers, A. M. L. M., and Leermakers, C. A. J. (2012). Review on the effects of dual-fuel operation, using diesel and gaseous fuels, on emissions and performance. SAE Technical Paper No. 2012-01-0869.

Wei, L., and Geng, P. (2016). A review on natural gas/diesel dual fuel combustion, emissions and performance. Fuel Process. Technol. 142, 264-278. doi:10.1016/j. fuproc.2015.09.018

Yang, B., Xi, C., Wei, X., Zeng, K., and Lai, M. C. (2015). Parametric investigation of natural gas port injection and diesel pilot injection on the combustion and emissions of a turbocharged common rail dual-fuel engine at low load. Appl. Energy. 143, 130-137. doi:10.1016/j.apenergy.2015.01.037

Yousefi, A., Guo, H., and Birouk, M. (2018). An experimental and numerical study on diesel injection split of a natural gas/diesel dual-fuel engine at a low engine load. Fuel. 212, 332-346. doi:10.1016/j.fuel.2017.10.053

Yousefi, A., Guo, H., and Birouk, M. (2019). Effect of diesel injection timing on the combustion of natural gas/diesel dual-fuel engine at low-high load and lowhigh speed conditions. Fuel. 235, 838-846.

Conflict of Interest: The authors declare that the research was conducted in the absence of any commercial or financial relationships that could be construed as a potential conflict of interest.

Copyright (c) 2020 Dev, Guo and Liko. This is an open-access article distributed under the terms of the Creative Commons Attribution License (CC BY). The use, distribution or reproduction in other forums is permitted, provided the original author(s) and the copyright owner(s) are credited and that the original publication in this journal is cited, in accordance with accepted academic practice. No use, distribution or reproduction is permitted which does not comply with these terms. 